\section{THE LEGACY OF WOMEN TO CRYSTALLOGRAPHY}

\author{
Julia Sanz-Aparicio \\ Instituto de Química-Física Rocasolano \\ Consejo Superior de Investigaciones Científicas \\ xjulia@iqfr.csic.es
}

Citation/Cómo citar este artículo: Sanz-Aparicio, J. (2015). "The Legacy of Women to Crystallography". Arbor, 191 (772): a216. doi: http://dx.doi.org/10.3989/arbor.2015.772n2002

Received: September 12, 2014. Accepted: February 13, 2015.

ABSTRACT: It is common to hear that X-ray crystallography is particularly welcoming to women. This assertion is perhaps based in the crucial contribution that a few brilliant women made to crystallography in the very early days. Therefore, this chapter will be mainly dedicated to honour the exceptional legacy of Kathleen Lonsdale, Dorothy Hodgkin, Rosalind Franklin and Isabella Karle, who were pioneers in a time when there was a strong discrimination against women in all aspects of life. Other prominent women, like Caroline MacGillavry, Olga Kennard, Eleanor Dodson, Louise Johnson, Jenny Glusker, Jane Richardson, among others, contributed to disseminate crystallography worldwide, providing the fundamental tools that resulted in the modern crystallography. The outstanding results that crystallography have provided to life sciences in the last years is well represented by the Nobel Prize awarded to Ada Yonath in 2009 for its contribution to the understanding of ribosome, the largest structure solved up-to-now.

KEYWORDS: science; scientists; discrimination; gender balance; women; female pioneers.

\section{EL LEGADO DE LAS MUJERES EN CRISTALOGRAFÍA}

Copyright: $@ 2015$ CSIC. This is an open-access article distributed under the terms of the Creative Commons Attribution-Non Commercial (by-nc) Spain 3.0 License.
RESUMEN: Existe la impresión de que la cristalografía ha sido una ciencia donde las mujeres han estado más representadas que en otras disciplinas. Esto se debe a la contribución esencial de unas cuantas científicas excepcionales en los inicios de la nueva ciencia. Por tanto, este capítulo pretende reconocer especialmente el legado de Kathleen Lonsdale, Dorothy Hodgkin, Rosalind Franklin e Isabella Karle, que fueron verdaderas pioneras en tiempos en que las mujeres tenían que enfrentarse a una fuerte discriminación social. Otras científicas destacadas, como Caroline MacGillavry, Olga Kennard, Eleanor Dodson, Louise Johnson, Jenny Glusker o Jane Richardson, contribuyeron al desarrollo de los procedimientos fundamentales que configuraron la cristalografía moderna. Los espectaculares resultados que la cristalografía ha aportado a las ciencias de la vida están bien representados en el Premio Nobel concedido a Ada Yonath en 2009 por su contribución al estudio del ribosoma, la mayor estructura determinada hasta el momento.

PALABRAS CLAVE: ciencia; científicas; discriminación; igualdad de género; mujeres pioneras. 


\section{THE BEGINNINGS}

The 22nd December 1895, Wilhelm C. Röntgen by using an as yet unknown radiation took the famous picture that would change drastically his life and the future of science. This picture, which showed the shadows produced by the hand bones of his wife Bertha wearing a ring, published the 5th January 1896 , and the discovery of that radiation that he called $X$ rays, provided him the Nobel Prize on Physics five years later. This discovery marked the beginnings of modern crystallography and incidentally the contribution of women to this novel scientific discipline. The $X$-rays found immediate applications in medicine and soon were applied for crystal structure determination by using the diffraction phenomena. It was not easy to pass from observation of bones to atoms and the initial trials were concentrated on small, highly symmetrical molecules. In 1913, Bragg published the first structural analysis of diamond, study that would be recovered later on by Kathleen Lonsdale. Some excellent scientists like John Desmond Bernal, Rosalind Franklin and Dorothy Hodgkin were so courageous to focus on biologically relevant molecules despite their size and complexity.

The early days of crystallography are, thus, replete with excellent female scientists. Since X-ray crystallography was born during the second decade of the 20th century, and only developed after World War I, the field is relatively new and perhaps more free of traditional prejudices. The early appearance and welcome of a few brilliant women into the laboratories of the Braggs was crucial. Many of the co-workers of these women, especially J.D. Bernal (1901-1971), later carried on the tradition of inviting women students and colleagues into their own laboratories. The first influential women crystallographers were Kathleen Lonsdale (1903-1971), a student and later colleague of the elder Bragg, and Dorothy Crowfoot Hodgkin (1910-1994), who had worked with Bernal. In turn, Lonsdale's and Hodgkin's own laboratories included many male and female graduate students and visiting scholars. This support did much to remove the barriers to women entering the physical sciences in the 1920s and 1930s. Even though, these extraordinary women had to fight against the difficulties of combining marriage and a family with a professional career, which was especially difficult by that time. Kathleen Lonsdale, who always advocated greater participation of women in science, and knew first-hand these difficulties, said in 1970: "Any country that wants to make full use of all its potential scientists and tech- nologists could do so, but it must not expect to get the women quite so simply as it gets the men. ... It is utopian, then, to suggest that any country that really wants married women to return to a scientific career, when her children no longer need her physical presence, should make special arrangements to encourage her to do so?".

\section{Dame Kathleen Lonsdale, Lonsdaleite Is For Ever}

\section{(1903-1971)}

Kathleen Yardley, later Kathleen Lonsdale, was born on January 28, 1903 in Newbridge, Ireland. Her discovery in 1929 that the benzene ring was flat, using X-ray diffraction methods, led to her being considered as one of the leading women in science (Figure 1). Although she is not particularly well known outside her own subject, she played a fundamental role in establishing the science of crystallography and along her scientific career scored several important firsts. She was the first woman (together with the microbiologist Marjory Stephenson) admitted as a fellow to the Royal Society, and the first female tenured professor at University College London (UCL). In 1966, she was elected as the first woman President of the International Union of Crystallography, and the first woman to hold the post of president of the British Association for the Advancement of Science. In 1966, the "Ionsdaleite", a rare form of meteoric diamond, was named for her.

She was encouraged to work in the new field of X-ray crystallography by W. H. Bragg. But Lonsdale made the most of this opportunity and her abilities, despite her family background and the heavy demands of her own family life. She was the youngest of ten children and her father was a heavy drinker. In 1908, when Kathleen was five years old, her parents were separated. Her mother moved the family to Seven Kings, a small town east of London. From 1908 to 1914 Kathleen attended Downshall Elementary School in Seven Kings and then won a scholarship to Ilford County High School for Girls. She was a good student, especially in mathematics and science. However, she had to attend classes in physics, chemistry and mathematics at the boys' high school because the girls' school didn't offer these subjects. Kathleen did well in her exams and won a county major scholarship, with distinctions in six subjects. She was allowed to enter Bedford College for Women, part of the University of London, at 16 . She first read mathematics but at the end of her first year switched to physics, against the advice of her old headmistress who said she would never distinguish herself in physics! She graduat- 
Figure 1. Doing the calculations by hand, Kathleen Lonsdale was the first to use Fourier spectral methods while solving the structure of hexachlorobenzene in 1931. After 60 years controversy, her results showed conclusively that the benzene ring was flat.

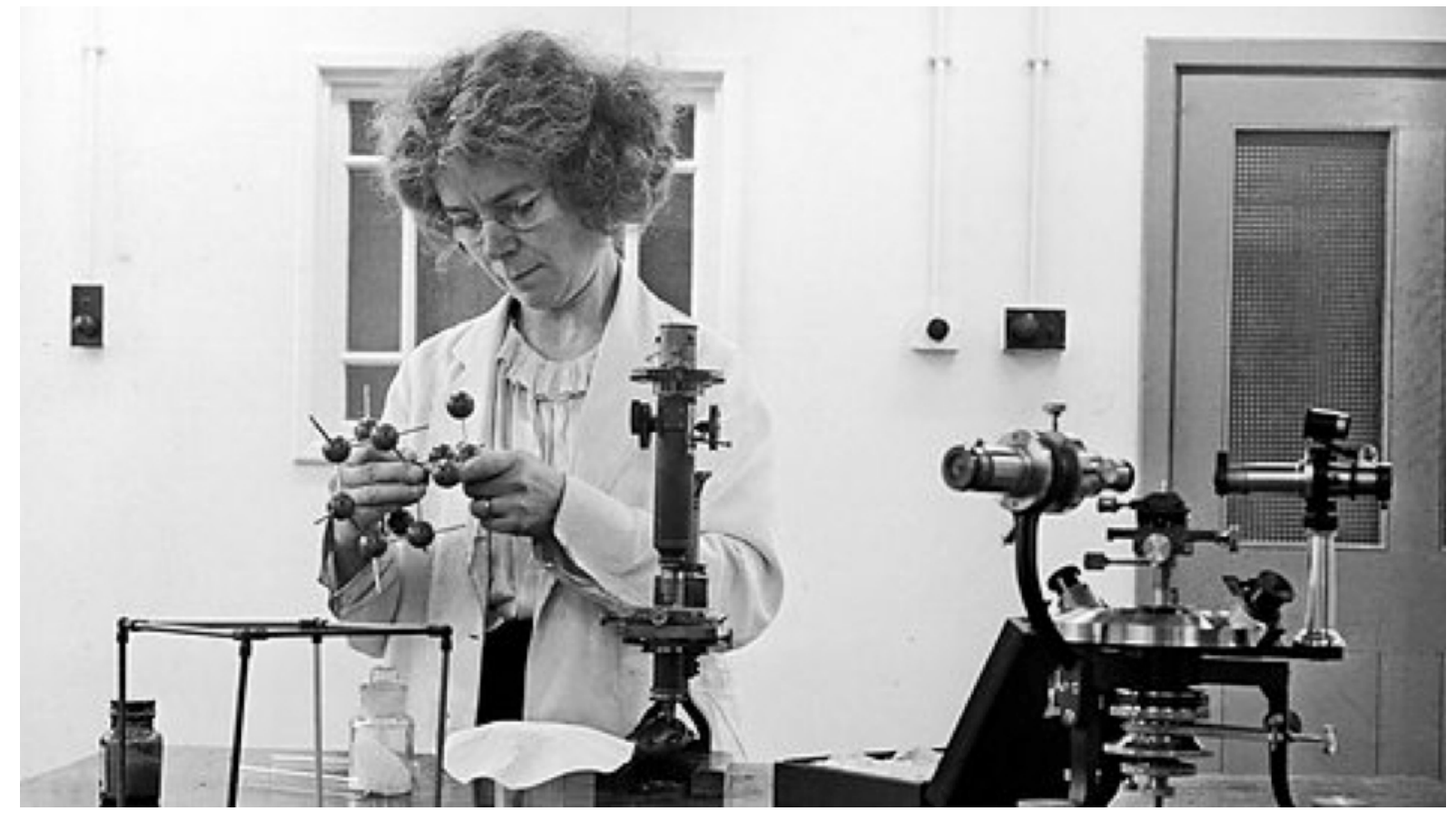

ed at the head of her class, receiving the highest marks in ten years, and among her oral examiners was William H. Bragg, the 1915 Nobel Laureate in Physics. He was so impressed with her academic performance that he invited her to work with him and a team of scientists using X-ray technology to explore the crystal structure of organic compounds.

Lonsdale worked with Bragg from 1922 to 1927, first at University College, London, and then at the Royal Institution. During these years she also completed her research for a master's thesis on the structure of succinic acid and related compounds. During this period, Kathleen and William T. Astbury, began their collaboration on a set of 230 space group tables which, published in 1924, became an indispensable tool for crystallographers.

On August 27, 1927, she married a colleague, Thomas Lonsdale, who was a fellow student of hers. They moved from London to Leeds, where her husband worked for the British Silk Research Association by day and completed his doctoral dissertation on the torsional strengths of metals by night. In Leeds, C. K. Ingold in the chemistry department gave her some crystals of hexamethylbenzene to study. Her results showed conclusively that the benzene ring was flat, something that chemists had been arguing about for 60 years, and supposed an important milestone in organic chemistry. Lonsdale also applied Fourier methods for the first time to analyse X-ray patterns in solving the structure of hexachlorobenzene (Lonsdale, 1931). What is most outstanding is that Kathleen did her calculations by hand!

In 1930, Kathleen returned to London following her husband, who had found a permanent post at the Ministry of Transport. Between 1929 and 1934, Lonsdale gave birth to their three children; she worked at home during this period, developing formulae for the structure factor tables. These formulas were published in 1936 as "Simplified Structure Factor and Electron Density Formulae for the 230 Space-Groups of Mathematical Crystallography" (Lonsdale, 1936). For the study of ethane derivatives contained in this book, Lonsdale received her doctorate of science. In 1934, Lonsdale returned to the Royal Institution, where she would work with Bragg until his death in 1942. Upon her return, however, she found that no X-ray equipment was available. Forced to manage with a large electromagnet, Lonsdale undertook experimental work that eventually proved the difference between 
sigma and pi electronic orbitals, thus establishing the existence of molecular orbitals. She then turned her attentions to the field of thermal vibrations, finding that divergent $\mathrm{X}$-ray beams could be used to measure the distance between carbon atoms.

Lonsdale was made a fellow of the Royal Society in 1945, and in 1946 she founded her own Crystallography Department at University College, London. In 1949, Lonsdale was named Professor of Chemistry at the college, and head of the Department of Crystallography, her first permanent academic post following years of living from one grant to the next. Only then, at the age of 43 , did she start to build up her own research school and get involved in teaching. During these years, she wrote a popular textbook, Crystals and X-Rays (1948), and served as editor-in-chief of the first three volumes of the International X-Ray Tables (1952, 1959, and 1962). In 1949, Lonsdale began working with the South African scientist Judith Grenville-Wells (later Milledge), eventually collaborating with her on a study of diamonds, as well as on studies of minerals at high temperatures and high pressures, and how solid-state reactions work. In the 1960s, Lonsdale became fascinated with body stones, and she undertook extensive chemical and demographic studies on the subject. In 1965, when Thomas retired, the Lonsdales moved to Bexhill-on-Sea, which meant that Kathleen had to shuttle for five hours each day to work. She retired from University College in 1968 and became an emeritus professor at $\mathrm{UCL}$, but she carried on working and publishing papers to the end of her life. She was ill for some time with cancer and was admitted to hospital in December 1970, but carried on working from her sick-bed. Shortly after celebrating Thomas' 70th birthday, she died from cancer, on April 1, 1971.

Lonsdale and her husband were committed pacifists. They became Quakers in 1936 and together worked toward world peace, as well as prison reform. During World War II, she and her husband gave shelter to refugees, and in 1943 Lonsdale spent a month in jail for refusing to register for war duties and then refusing to pay a fine of two pounds. In 1956, she wrote a book in reaction to extensive nuclear testing by the United States, the Soviet Union, and Great Britain entitled Is Peace Possible? The book explored the relationship between world peace and world population needs, as viewed through her own experience as the youngest of ten children. Lonsdale was against nuclear weapons of any kind, and she worked tirelessly for world peace.
She was often invited to speak on non-scientific topics at home and abroad, including science and religion, and the role of women in science. She had very strong views on the need to encourage and support women who wanted to have a family and use their scientific. In Fifty years of X-ray Diffraction, Kathleen told a story about Sir Alfred Yarrow, who had endowed several research fellowships at the Royal Institution. He had a theory that intelligence was inherited on the maternal side. Inconsistently, he argued that women should not be allowed in the laboratory because they only leave to get married. Kathleen asked, "where his intelligent mothers would come from if only those with no professions were allowed to marry?"

Kathleen Lonsdale is someone we can look up to, not only as a great scientist who achieved much, despite many difficulties, but also as a good human being.

\section{Dorothy Crowfoot Hodgkin, The Nobel Prize} (1910-1994)

It was Ernst B. Chain, Alexander Fleming, and Howard Florey who discovered penicillin, but it was Dorothy Hodgkin (Figure 2) who, by using X-ray crystallography, revealed its structure. Before Dorothy Hodgkin, the procedure was not capable of analysing such complex structures, but through years of tireless dedication and hours of hard work, she advanced X-ray crystallography to be able to examine all sorts of intricate molecules (Hodgkin, 1965). Hodgkin discovered the structures of insulin and vitamin B12 (the latter of which earned her the Nobel Prize in Chemistry in 1964).

Dorothy Crowfoot was born on May 12th, 1910 in Cairo, Egypt. Her father, John Winter Crowfoot, was archaeologist by profession and also worked for Ministry of Education in Khartoum, Sudan. Dorothy followed him to several excavations, including the Byzantine ruins in Jerash, Jordan (http://bit.ly/1fnm8yf). At the beginning of the 1930s presented her doctoral thesis on the study of halides compounds of thallium, which developed at Somerville College en Oxford. In 1932, she moved to Cambridge, where she started research on molecules of biological interest at the laboratory of John D. Bernal. The crystalline samples analysed, in a preliminary way, were vitamin B1, vitamin D, cholesterol, and pepsin. In the summer of 1934, the Bernal team took the first picture of a protein: pepsin. Unfortunately, on that important occasion Dorothy was absent for health reasons. A year later he obtained the pattern of diffraction for a crystal of insulin, substance that was her great challenge and passion along all her life: determine its structure completely took her 33 years! 
Figure 2. Dorothy Hodgkin won the 1964 Nobel Prize in Chemistry "for her studies for the determinations by X-ray techniques of the structures of important biochemical substances" (http://bit.ly/1fnm8yf). In 1955, Pauling sent a letter to her "to congratulate you on the wonderful job that you have done on vitamin B12. I find it hard to believe, although very satisfying, that the methods of X-ray crystallography can be used so effectively on such a complex molecule".

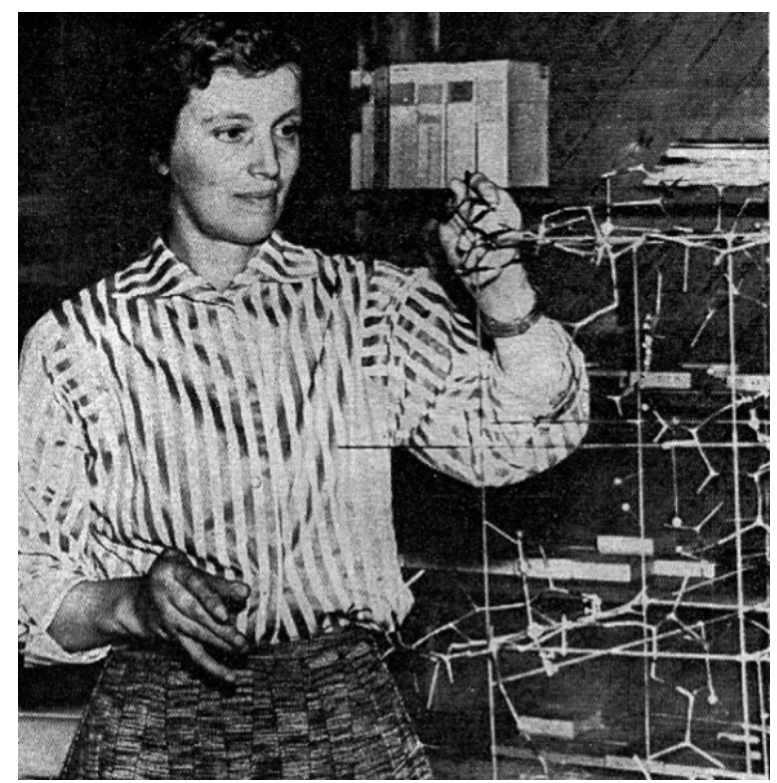

To understand the meaning of this, it is necessary to put the task in perspective. During the years from the 1930s onwards, that Hodgkin was carrying out her research, all analyses had to be carried out without the assistance of computers. This meant that the calculations required to move from a hypothesised model of the crystal packing to a prediction of the resulting diffraction pattern had to be carried out laboriously by hand. The larger the molecule, the harder the calculations as the more terms there were to add in. This needed to be an iterative process since if, as it was usually the case, the initial hypothesised structure proved not to lead to a diffraction pattern consistent with the experimental evidence, this could mean repeating huge sets of calculations until a good match was found. For a molecule such as insulin the complexity of the molecule (and hence the calculations), coupled with the experimental challenges of growing large enough single crystals suitable for the X-ray technique, presented formidable difficulties. In fact, though it was an aspiration of Hodgkin's to unravel its structure from as early in her research career as 1934, its structure defeated even her prodigious skills until 1969, some years after she had already won the Nobel Prize.

After three years working in Bernal's group, she returned to Oxford in 1935 and set up his own laboratory in collaboration with $\mathrm{C}$. $\mathrm{H}$. Carlisle where she analysed the structure of iodide of cholesterol by $\mathrm{X}$ ray diffraction. During the Second World War, most efforts in scientific research were directed to applied science and penicillin was a topic that was taken from several fronts. In 1949 she concluded the study, begun seven years earlier, on the determination of the structure of penicillin through their derivatives and products of degradation. This project was executed using "punched cards" for the calculations in three dimensions. The contribution of Dorothy was decisive for the synthesis of this antibiotic. For a period of six years she gathered information about the patterns of diffraction from crystals of vitamin B12 and its analogues. The complexity of data processing required the simultaneous use of three computers: two in England (Manchester and Teddington) and another in United States (Los Angeles). Hodgkin completed the structure of this vitamin, results that were be of great benefit in the field of medicine in 1956.

Her outstanding work was soon recognized and, in 1964, she knew that she had been distinguished as single winner of the Nobel Prize in Chemistry "for her determinations by X-ray techniques of the structures of important biochemical substances". She was the third female Nobel Laureate in Chemistry after Marie Curie and her daughter. This was not the only distinction as her contribution was recognised with many distinctions during her career, starting with fellowship of the Royal Society in 1946, the RS Royal Medal in 1956 and the Order of Merit in 1965. Somerville College at Cambridge still holds an annual Dorothy Hodgkin Memorial Lecture in March (to coincide with the International Women's Festival) that has had many notable speakers over the years.

Hodgkin was a woman not prepared to let her gender get in the way of her work. She was one of the first fellows at the College to be married and in 1938, not only the first fellow at Somerville to start a family whilst in post but also the first woman to receive maternity pay at Oxford University. However, it seems that the world may have been less willing to forget her gender. It is amazing to remember the way her Nobel Prize was announced in the British newspaper! The Daily Telegraph announced "British woman wins Nobel Prize $-£ 18,750$ prize to mother of three". The Daily Mail was even briefer in its headline "Oxford housewife wins Nobel". 
The Observer in its write-up commented "affable-looking housewife Mrs Hodgkin" had won the prize "for a thoroughly unhousewifely skill: the structure of crystals of great chemical interest".

Maybe her own experience inspired Hodgkin's along her long research life, and she supervised or collaborated with a host of other women. Crystallography still seems to have something much closer to gender balance in its teams than many other branches of physics and chemistry, probably significantly facilitated by the way both Bernal and Hodgkin nurtured female talent passing through their laboratories, something that could not be taken for granted among senior scientists. In Hodgkin's case key women who themselves went on to have long and successful scientific careers included Clara Shoemaker, Jenny Pickworth Gluster, Eleanor Dodson and Judith Howard. Of these, the last three are still alive and active. Less successful a scientist, who worked briefly with Hodgkin, was Margaret Roberts, better known to the world as Margaret Thatcher.

Throughout her constant struggle with rheumatoid arthritis, Hodgkin continued to excel at crystallographic research despite its delicate and precise nature. In 1970 she was elected Chancellor of the University of Bristol, an honorary position that allowed her to continue her work at Oxford until her retirement in 1977. She was also active in various political causes, most notably the Pugwash campaign against nuclear weap- ons on whose behalf she travelled all over the world. In the later part of her career, she also supported scientists in developing countries.

Dorothy Hodgkin, a pioneer of protein crystallography, was described by her biographer as a brilliant scientist "whose humanity recognized no national boundaries."

\section{Rosalind Franklin: The Intensity Of A Brief Life} (1920-1958)

There is probably no other woman scientist with as much controversy surrounding her life and work as Rosalind Franklin (Figure 3). Franklin was responsible for much of the research and discovery work that led to the understanding of the structure of deoxyribonucleic acid, DNA. James Watson, Francis Crick, and Maurice Wilkins received a Nobel Prize for the double-helix model of DNA in 1962, four years after Franklin's death at age 37 from ovarian cancer. The story of DNA is a tale of competition and intrigue, told one way in James Watson's book The Double Helix. A biography of Franklin, as well as numerous protests against Watson's portrait of Franklin by her colleagues and reviewers, helped to set her public image straight. Her tragically short life is now recognized as one of brilliant scientific achievement.

Rosalind Elsie Franklin was born on July 25, 1920 in London, UK. She was educated at a private school in London where she studied physics and chemistry

Figure 3. Rosalind Franklin and her X-ray image confirming the helical structure of DNA shown to Watson without her approval or knowledge. Although this image and her analysis provided valuable insight into the structure of DNA, Franklin's scientific contributions to the discovery of the double helix are often overlooked.

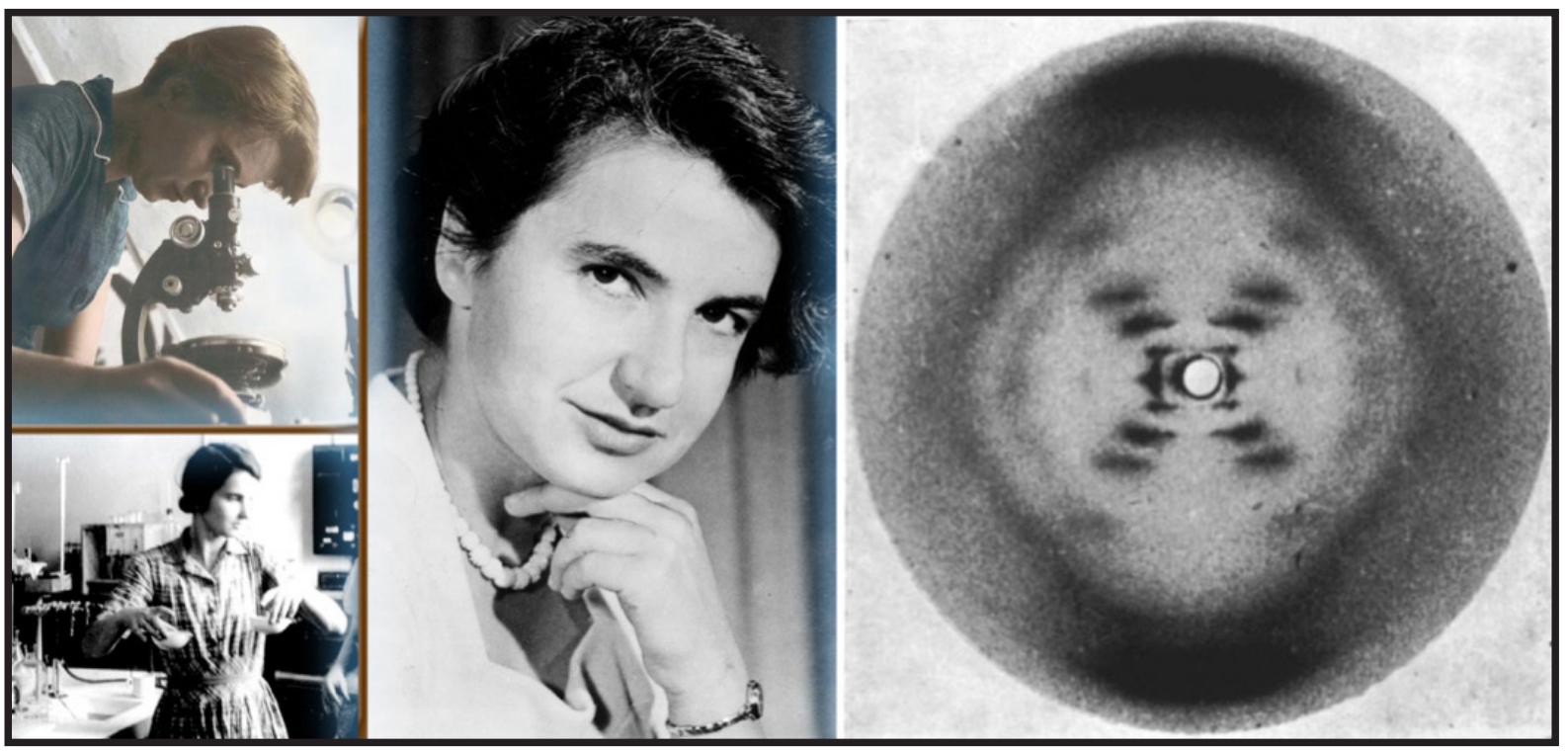


from an early age, at an advanced level, especially so for a woman at that time. In the 1930s her father was active at the Centre at Woburn House, which aided Jews who had escaped from Nazi Germany. Rosalind did volunteer work there while she was at school. When she was 15 , she decided to become a scientist. Her father was decidedly against higher education for women and wanted Rosalind to be a social worker. Ultimately he capitulated, and in 1938 she enrolled at Newnham College, Cambridge, graduating in 1941. She held a graduate fellowship for a year, but quit in 1942 to work at the British Coal Utilization Research Association, where she made fundamental studies of carbon and graphite microstructures. This work was the basis of her doctorate in physical chemistry, which she earned from Cambridge University in 1945.

By that time in France, Marcel Mathieu, disciple of William H. Bragg in the Royal Institution, was exploring changes in the shape of graphite due to the variations of crystallization temperature and pressure. In February 1947, Rosalind Franklin went to Paris invited by Mathieu and under Jacques Mering learned the X-ray crystallographic methods. During her stay in France, she published five articles about the crystallization of graphite, which are the most cited, on the subject, until today.

In January 1951, Franklin began working as a research associate at the King's College London in the biophysics unit with John Randall. It was in Randall's lab that she crossed paths with Maurice Wilkins. She and Wilkins led separate research groups and had separate projects, although both were concerned with DNA. When Randall gave Franklin responsibility for her DNA project, no one had worked on it for months. Wilkins was away at the time, and when he returned he misunderstood her role, behaving as though she were a technical assistant. Both scientists were actually peers. His mistake, acknowledged but never overcome, was not surprising given the climate for women at the university by then. Only males were allowed in the university dining rooms, and after hours Franklin's colleagues went to men-only pubs.

But Franklin persisted on the DNA project (Maddox, 2003). The X-ray diffraction technique learned in France was of great utility, since the graphite and the DNA diffraction patterns had in common its low sharpness. Franklin used a high-resolution camera to get these patterns by making very thin fibres of DNA, bundling them and hitting them with a super-fine X-ray beam. Her excellent work was commented by Bernal who said that her photographs were the more beautiful taken so far for any substance. Franklin and her student Raymond Gosling took increasingly clear X-ray diffraction photos of DNA, and quickly discovered that there were two forms, wet and dry, which produced very different pictures. She realized that the wet form (B form) was probably helical in structure, with the phosphates on the outside of the ribose chains. Her mathematical analyses of the dry form ( $A$ form) diffractions, however, did not indicate a helical structure, and she spent over a year trying to resolve the differences.

In November 1951, Franklin presented her results on the $A$ and $B$ forms to an audience that included James Watson, who was working with Francis Crick in Cambridge on their own DNA model. On hearing her lecture, the two scientists built their first model of DNA: a triple helix with the bases on the outside. Soon after, in May 1952, Franklin got her first good photograph of the B form of DNA, the later popular "Photograph 51", which became famous as critical evidence in identifying the helical structure of DNA. The photo was acquired through 100 hours of X-ray exposure from a machine Franklin herself had adjusted. By early 1953 Rosalind Franklin came very close to solving the DNA structure.

However, the personal conflict of Rosalind with her colleague Maurice Wilkins, would end up costing her greatly. In January 1953, Wilkins changed the course of DNA history by disclosing without Franklin's permission or knowledge her "Photo 51" to the competing scientists James Watson and Francis Crick. The two scientists did in fact use what they saw in Photo 51 as the basis for their famous model of DNA, which they published on March 7, 1953, and for which they received a Nobel Prize in Physiology or Medicine in 1962, together with Maurice Wilkins. Crick and Watson were also able to take most of the credit for the finding: when publishing their model in Nature magazine in April 1953, they included a footnote acknowledging that they were "stimulated by a general knowledge" of Franklin's and Wilkins' unpublished contributions, when in fact, much of their work was rooted in Franklin's photo and findings. Randall and the Cambridge laboratory director came to an agreement, and both Wilkins' and Franklin's articles were published second and third in the same issue of $\mathrm{Na}$ ture. Still, it appeared that their articles were merely supporting Crick and Watson's.

A debate about the amount of credit due to Franklin continues. What is clear is that she did have a meaningful role in learning the structure of DNA and that 
she was a scientist of the first rank. As it was clear that she was left out from the DNA research, Franklin moved to J. D. Bernal's lab at Birkbeck College, where she did very fruitful work on the tobacco mosaic virus. Years later, Aaron Klug, one of her colleagues and collaborators, received the Nobel Prize in Chemistry for research in this topic and its contribution to crystallography. In the summer of 1956, she knew she had cancer and undertook one last project: structural analysis of the poliovirus. During her last few years, she received increasing numbers of invitations to speak at conferences all over the world, and it is likely that her virus work would have earned awards and other professional recognition, had she lived to continue it. She continued working until her death on April 16, 1958, at the age of 37 . One thing is certain: she died without ever knowing the true magnitude of her contribution to the science of life.

Throughout her 16-year career, Franklin published 19 articles on coals and carbons, 5 on DNA, and 21 on viruses. But the discovery of the structure of DNA was the single most important advance of modern biology. Quite simply, it changed the future of healthcare forever.

\section{Isabella Karle, The Omission Of An Exceptional} Experimentalist

Isabella Karle, born Lugoski, is a true pioneer of physical chemistry, who invented new methods, using first electron and then X-ray diffraction, to study the structure of molecules (Karle, 1973).

Isabella Karle (Figure 4) was worn in Detroit, within a family of Polish immigrants. She attended the local public school, where a female chemistry teacher encouraged her to pursuit the field as a career. She was quite a precocious child, receiving her M.S. degree in physical chemistry from the University of Michigan in 1942. However, things were not easy in those days, as she ran into serious financial problems since teaching assistant positions at the University of Michigan were reserved exclusively for male doctoral students. She managed to stay at school on an American Association of University Women fellowship, and in 1943 also became a Rackham fellow. She received her Ph.D. in physical chemistry from the University of Michigan in 1944, at the age of twenty-two.

While at Michigan, she married her fellow chemistry grad student Jerome Karle. In 1943, the couple worked briefly on the Manhattan Project at the
University of Chicago, the U.S. government research project that during the years $1942-45$ produced the first atomic bombs. Isabella was one of the highestranking scientists on the team, developing techniques to extract plutonium chloride from a mixture containing its oxide. They returned to Ann Arbor (Michigan), where Isabella became the first female member of the chemistry faculty.

Figure 4. Isabella Karle was a brilliant experimentalist that made crucial contributions to the development of direct methods to solve the structure of molecules by crystallography. The Nobel Committee ignored her hours of work collecting the experimental evidence necessary to validate the theory, when they awarded the 1985 Nobel Prize in Chemistry to her husband Jerome, along with his colleague Herbert Hauptman.

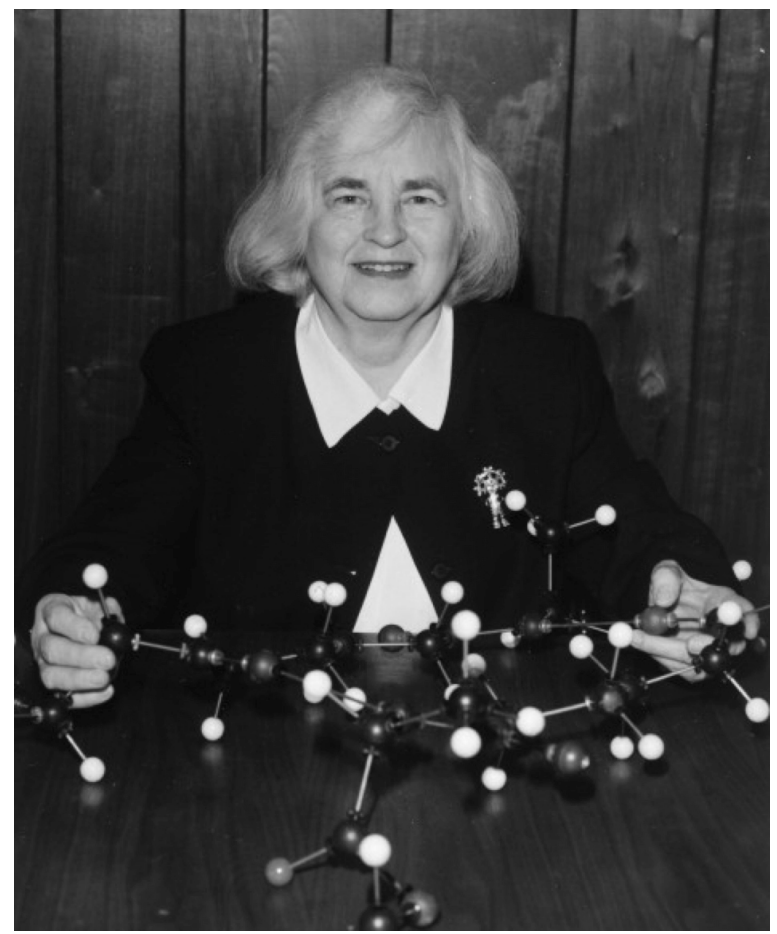

By 1946, they began working at the Naval Research Laboratory (N.R.L.), where they undertook the research that would last for the rest of their scientific careers. Jerome had developed a series of equations to allow "direct" analysis of the diffraction pattern, which would be the basis for the development of direct methods to determine crystal structures. However, Jerome's equations required experimental support to prove their correctness. It was necessary to collect $X$ ray data on crystals grown from large molecules, and then use these data to check the validity of the equations. That was 
the crucial participation of Isabella, who was a brilliant experimentalist and had to construct her own equipment for the task, even when she had never made it before. Eventually, she was in the maternity recovering from her first baby birth when she learned the technique from a textbook. Next, and once the experimental data were taken, it was necessary to make very large and complex calculations to solve the equations. Isabella and Jerome made then a very hard decision. They risk one-year funds from their laboratory to use an innovative computer created by IBM that would be able to greatly speed up the calculations. Indeed, it was a very happy moment when the computer, finally, provided the correct coordinates that validated Jerome's equations.

Isabella developed the practical aspects of the mathematical theory of crystallography, which revolutionized the types and complexity of problems that may be attacked by crystal-structure analysis. Her research drastically improved the speed and accuracy of chemical and biomedical analysis, and remains the basis of all advanced X-ray crystallography, including computerized programs, used around the world today. Thanks to Karle's process, the number of new molecular analyses published annually raised steeply from about 150 to over 10,000 by the beginning of this century. Isabella herself has identified and elucidated the structures of hundreds of important molecules. She was the first to publish the structure of many complex organic and inorganic substances, including steroids, alkaloids, toxins, ionophores, and especially peptides. Her first major success was in 1969, when she established the structure of venom extracted from South American frogs. This was followed in 1975 with the structure of valinomycin, a polypeptide that transports potassium ions across biological membranes. At the time it was the largest molecule to be worked out directly. In 1979 the structure of another peptide, antamanide, was solved.

In 1985, Jerome and his colleague Herbert Hauptman were awarded the Nobel Prize in Chemistry "for outstanding achievements in the development of direct methods for the determination of crystal structures" (http://bit.ly/1J5HXAA). Many crystallographers questioned the committee for ignoring the Isabella's essential contribution in solving the problem, through her brilliant experimental support. In any case, she never complained about the subject and said that she always felt her scientific work being well recognized. She had indeed received numerous National and International awards, as the Gregori Aminoff Prize from the Swedish Academy of Sciences in 1988, the Bijvoet Medal from the University of Utrecht, the Netherlands, in 1990, and a National Medal of Science in 1995, the United States' highest scientific honour.

Isabella and her husband retired from the Naval Research Laboratory on July 31, 2009, after a long life of dedication to work. Without her pioneering contributions to this field, much of the wonderful work that followed would not have been possible. Certainly, she is one of the utmost scientists of her generation.

\section{CRYSTALLOGRAPHY KEEPS GROWING}

The early efforts to make use of crystallography to analyse the internal structure of all kind of molecules were soon followed by many others. Caroline Henriette MacGillavry (1904-1993) was a Dutch chemist known for her discoveries on the use of $\mathrm{X}$-ray diffraction in crystallography. Caroline (Figure 5) began studying chemistry at the University of Amsterdam, where she became interested in the (then) new field of quantum mechanics. In 1932 she finished her studies and became a friend of J. H. Bijvoet, who interested her in crystallography, leading to her $1937 \mathrm{PhD}$ thesis on the subject. Working with X-ray diffraction, she became fascinated by the beauty of crystals that resulted from exactly the right interplay between order, regularity, colour and natural irregularities. This attraction made her to take up a position in the Crystallography Department as assistant to Bijvoet, where she was to work for the rest of her career. Together with Bijvoet she did research in electromagnetic diffraction and its use in crystallography and, after World War II, Caroline was one of the developers of direct methods, which brought her international repute. For many years she was head of the Chemical Crystallography Laboratory in Amsterdam and attended many international events as the first European Conference in Crystallography, organized by W.L. Bragg at the Royal Institution in London. Her great ability to express in concrete terms made her public lectures drew large audiences, attracting both scientists and non-scientists. Caroline became most famous for her book Symmetry aspects of M.C. Escher's periodic drawings on the works of the Dutchman Escher. She was intrigued by the symmetry in the Escher's work, which shows some similarities with her own work. The book gave the initial impetus drawing international attention to the artist. She retired in 1972 and left a substantial part of her inheritance to launch the MacGillavry Foundation that aims to support young researcher who contribute to the solution of problems of the developing countries. 
Figure 5. Carolina Henriette MacGillavry, who became a professor at the University of Amsterdam in 1957.

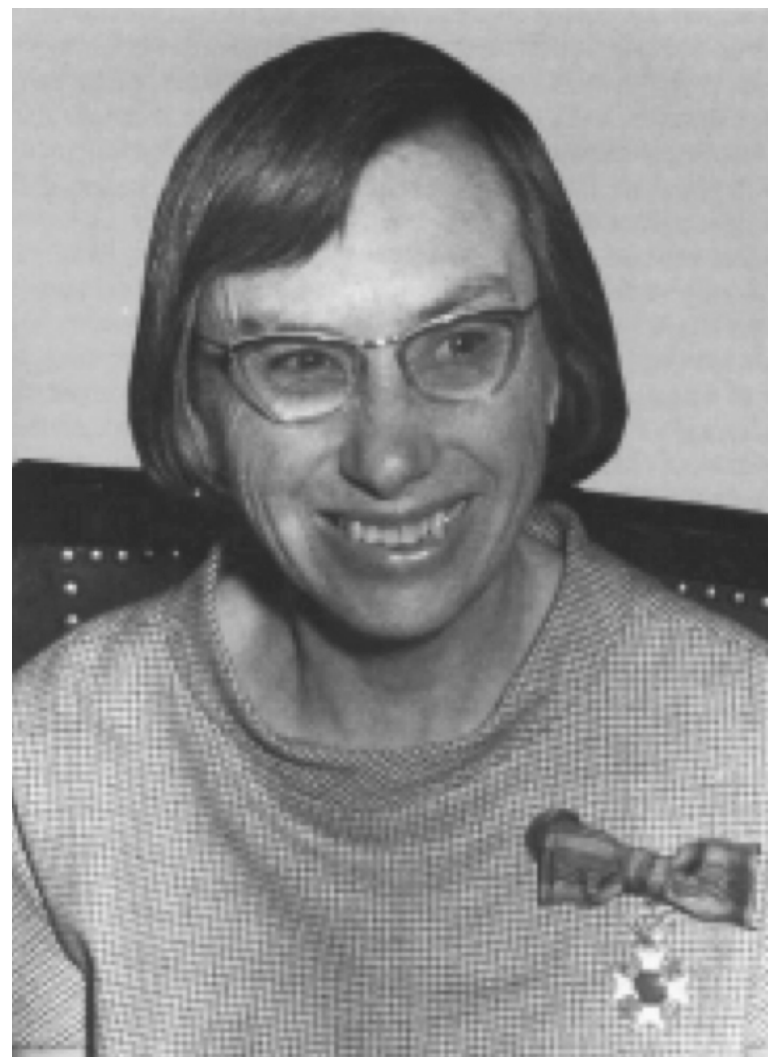

Following the legacy of the pioneers, British female scientists made many decisive contributions to the dissemination of crystallography. Special mention deserves the initiative of Olga Weisz Kennard (1924-) (Figure 6) who, in 1965, founded the Cambridge Crystallographic Data Centre (CCDC), being its Director for thirty years. CSD, the Cambridge Structural Database is one of the oldest numeric scientific databases created anyway in the world, providing a good example of the gradual transition from the traditional printed dissemination of data to the present electronic age. The database was intended, in Kennard's words, "to fulfil a dream of myself and a great scientist, the polymath J.D. Bernal: we had the passionate belief that the collective use of data would lead to the discovery of new knowledge that transcends the results of individual experiments". Her innovative idea coped successfully with the exponential growth of information, creating a computerizing database where information could be searched for and analysed using software developed by the CCDC. Today, the CSD stores experimental data for over 650,000 crystal structures and has become an indispensable tool for various fields, including drug development. Parallel with the development of the database, Kennard was very active in determining the structure of a variety of increasingly complex molecules, as the ATP (1970) and the first fragment of double helical DNA at atomic resolution (1978).

Figure 6. Olga Weisz Kennard, who founded the Cambridge Crystallographic Data Centre (CCDC). The data base produced by the CCDC stores experimental data for over 650,000 crystal structures and has become an indispensable tool for various fields, including drug development.

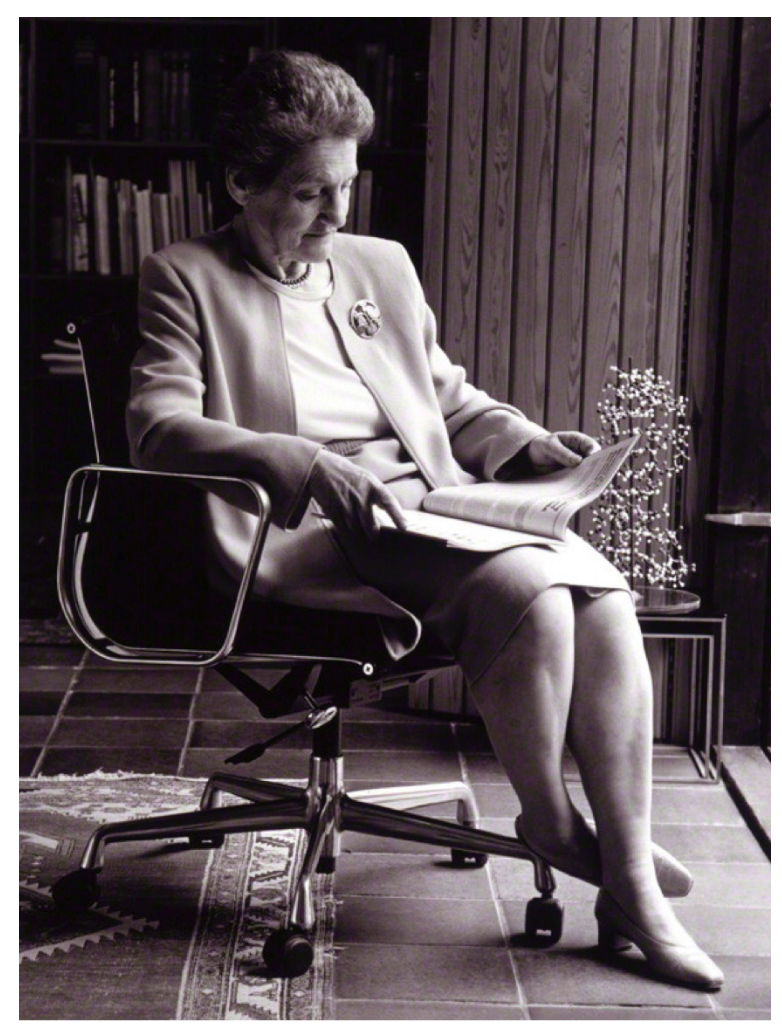

Other well-known British crystallographer is Eleanor MacPherson Dodson (Figure 7), who has played a key role in the development of mathematical and computational techniques to perform crystallography. Her career began in the 1960s when she was recruited for her mathematical skills to work with the Dorothy Hodgkin's group at Oxford, moving to York in 1976 with her husband Guy Dodson. She carried pioneering work to develop analytical tools that allow nonexperts to access modern crystallography, and all of this has been achieved working mainly part-time on short-term contracts fitting her work around bringing 
Figure 7. Eleanor Dodson, which began as Dorothy Hodgkin's technician, was the main instigator behind CCP4, the collaborative computing project that currently shares more than 250 software tools with protein crystallographers worldwide. In 2011 she became the only woman that has received the prestigious Ewald Prize, awarded by the IUCr triennially since 1987.

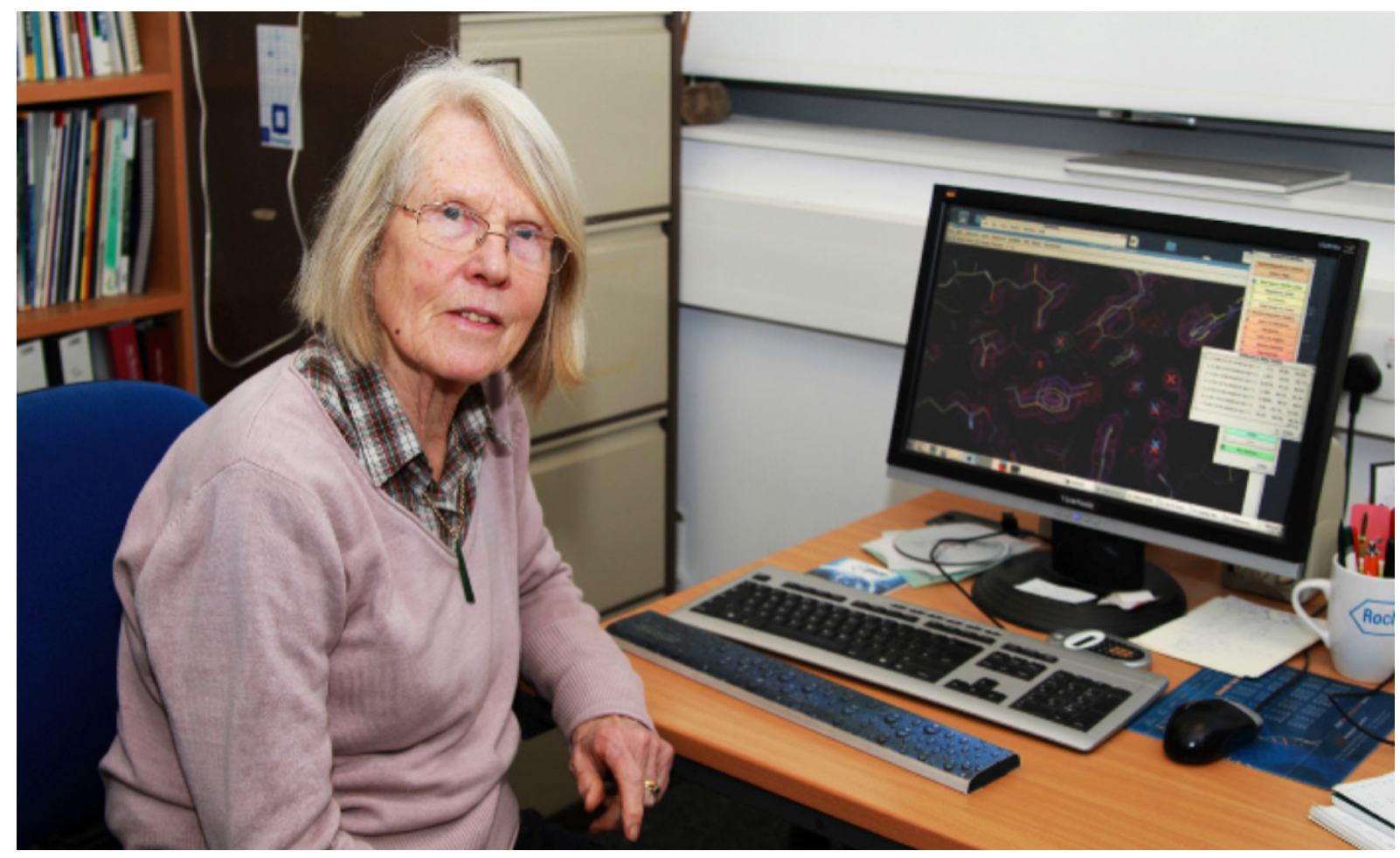

up a family of four children! She realised that much of the work going on then was not really biological science; rather it was work that could and should be done by computers. The huge problem was there were no agreed standards and almost no programs for the computers to use. Eleanor became the focal point in Oxford for these developments that led in 1974 to the founding by her and others of a computing cooperative, which in 1979 became CCP4 (Collaborative Computing Project number 4) a pioneer initiative to facilitate and distribute protein crystallography methods worldwide. The key of its and Eleanor's success has been to turn half described ideas and ill-defined theories into practical programs that work everywhere for everyone. Alongside central contribution Eleanor has made major contributions to the theory and practice of methods used to determine the atomic structures of macromolecules, such as molecular replacement, phasing and refinement. She has been a magnet for other crystallographers who came to work with her at York. She has taught generations of scientists, is known across the world to students, post-docs and group lead- ers not only for her almost daily contributions of tips, solution and advice to the crystallography bulletin board, but for a unique personal warmth. In 2011 Eleanor Dodson shared the ninth Ewald Prize Medal with C. Giacovazzo and G. M. Sheldrick for the enormous impact they have made on structural crystallography through the development of new methods that have been made available to users as constantly maintained and extended software. Also very influent was the British scientist Louise Johnson (1924-2012), who began her career as a doctoral student as part of a team at the Royal Institution under Lawrence Bragg and David Phillips that, in 1965, discovered the structure of lysozyme, the third protein and first enzyme ever solved by $\mathrm{X}$-ray crystallography. Her studies of how lysozyme acts on chemicals in cell walls began to probe the mystery of how it was able to break down the walls of bacterial cells, helping to kill the bacteria. These beginnings marked the course of her prominent scientific work always in the vanguard of enzymology. In her own laboratory at Oxford, where she was David Phillips Professor of Molecular Biophysics from 
1990 to 2007, Louise Johnson led a team of scientists who carried out many studies of the structure and behaviour of protein kinases in the regulation of the cell cycle, a work that is crucial in finding the causes of disease and for designing new drugs.

Throughout her career Louise remained at the cutting edge of developments in protein crystallography, introducing new techniques and exploiting new instrumentation that have enabled the elucidation of the structures of numerous complex proteins. In 2003, she became director for life sciences at the Diamond Light Source (Figure 8), the UK's national synchrotron science facility. She encouraged advances made possible by this powerful new source of X-rays, not only in structural biology at the molecular level, but also for $\mathrm{X}$-ray imaging of whole cells.

Figure 8. Louise Johnson was appointed as its first Director of Life Sciences Program in 2003 at the Diamond Light Source. She has been a pioneer in Structural Enzymology, her first contribution being the structure of lysozyme.

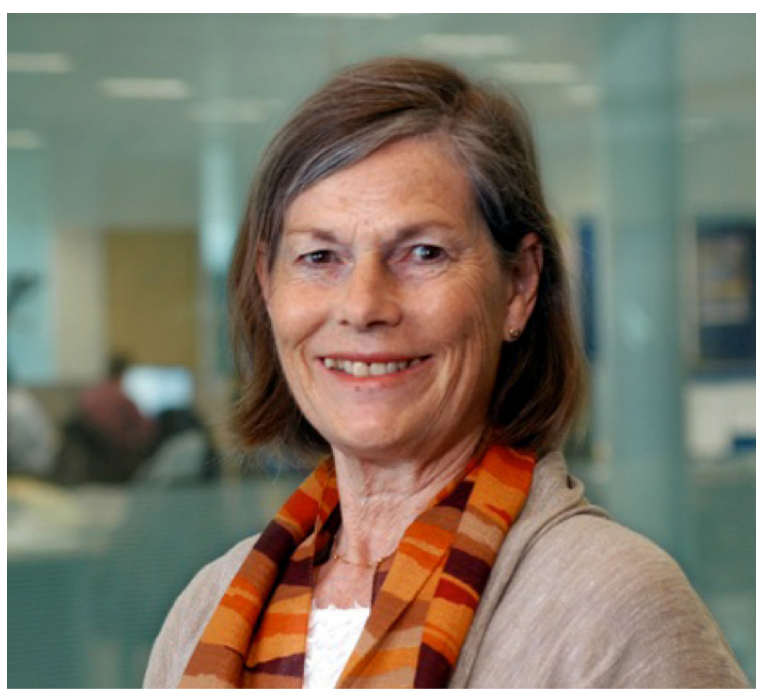

Jenny Pickworth Glusker (1931-) (Figure 9) born in Birmingham, England, started her career in Dorothy Hodgin's laboratory at Oxford, working on the hexacarboxylic acid derivative of vitamin B12. After completing her research work at Somerville College, she and her American fiancé moved to the United States to get married. After one-year stay at California, where Jenny worked with Linus Pauling, they moved to the Institute for Cancer Research at the Fox Chase Cancer Centre (Philadelphia) in 1956, to work in the laboratory headed by Arthur Lindo Patterson. With Patterson's approval and support, Glusker was able to work on a part-time basis while raising her three children. Her work on citrates expanded the understanding of the citric acid cycle, a series of reactions involving the breakdown of metabolic products, on a molecular level. After Patterson died in 1966, Jenny assumed control of the laboratory. In 1967, she was named associate member of the institute, and in 1979, she became a senior member. Glusker returned to the study of vitamin B12 and researched the structure of cancer-causing substances through the 1990s. She also became increasingly interested in the structure of macromolecular compounds. Glusker has been extremely active in the scientific community. One of her major interests is crystallography education; she is a prolific writer and editor and is internationally renowned by her popular textbook "Crystal Structure Analysis: A Primer" that was first published on 1971. This book has made available the crystal structure determination techniques to many non-specialist users, and has seen its third edition appearing in 2010 (Glusker and Trueblood, 2010).

Figure 9. Jenny Pickworth Glusker researched the structure of cancer-causing substances through the 1990 s and became increasingly interested in the structure of macromolecular compounds.

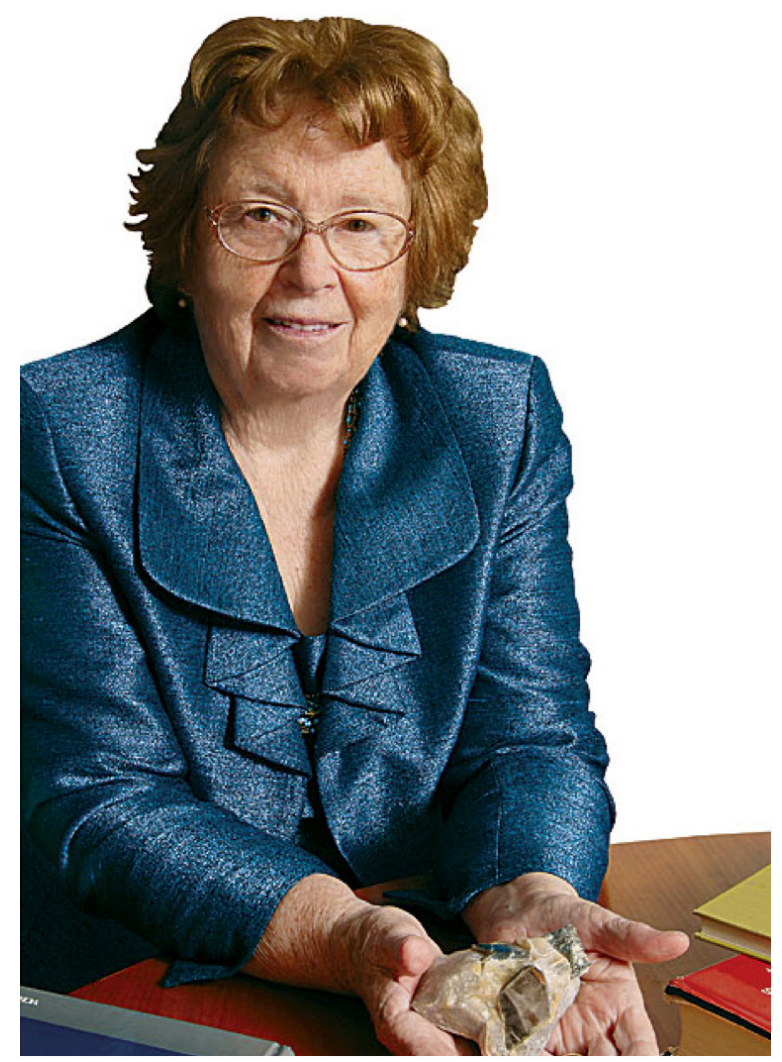


Jane S. Richardson (1941-) (Figure 10) is an American biophysicist who developed the Richardson diagram, or ribbon diagram, a method of representing the 3D structure of proteins, first published in 1981. These portraits, initially hand-drawn and now computer-painted, make sense of lots of X-ray crystallography data by showing proteins as intertwined ribbons. They demonstrate how the parts of these large molecules twist, fold, and unfold. Richardson's graphics became the standard for depicting proteins, helping scientists understand how proteins work and how to build them. Born in Teaneck, New Jersey, Richardson showed a great aptitude for science at an early age. In high school she placed third in the 1958 Westinghouse Science Talent Search by calculating the orbit of Sputnik, the only artificial satellite at the time, from observations on two successive nights! She got master's degrees in philosophy and in teaching from Harvard University in 1966. Finding herself unsuited for teaching high school, she went to work as an X-ray crystallographic technician, recording data in the same laboratory at the Massachusetts Institute of Technology where her husband, David, was then finishing his Ph.D. in chemistry. In 1970 the couple moved to Duke University, where David took a faculty position in the biochemistry department and Jane held a variety of "invisible" positions as a research assistant, nominally in a variety of departments due to her lack of a doctoral degree and the university's rules, later discarded, against employing a husband and wife in the same department. But the couple seem always to have maintained their scientific collaboration. External recognition-first by the MacArthur Foundation with a so-called "genius" award in 1985, and then by election to the National Academy of Sciences in 1991-moved Duke to grant her faculty appointments and eventually tenure in the department of biochemistry.

Many outstanding women fill the list of prominent crystallographers worldwide. I cannot finish these lines without remembering Sagrario MartínezCarrera (1925-2011) (Figure 11), who working for forty years at the Institute of Physical-Chemistry Rocasolano, in Madrid (at the Spanish National Research Council, CSIC), was pioneer in the development of the modern crystallography in Spain. She began her career in the early 50's, rather adverse times for science in the country and mainly for a female, but soon became compromised in imple-
Figure 10. Jane S. Richardson, the American biophysicist who developed the Richardson diagram, or ribbon diagram, a method of representing the 3D structure of proteins.

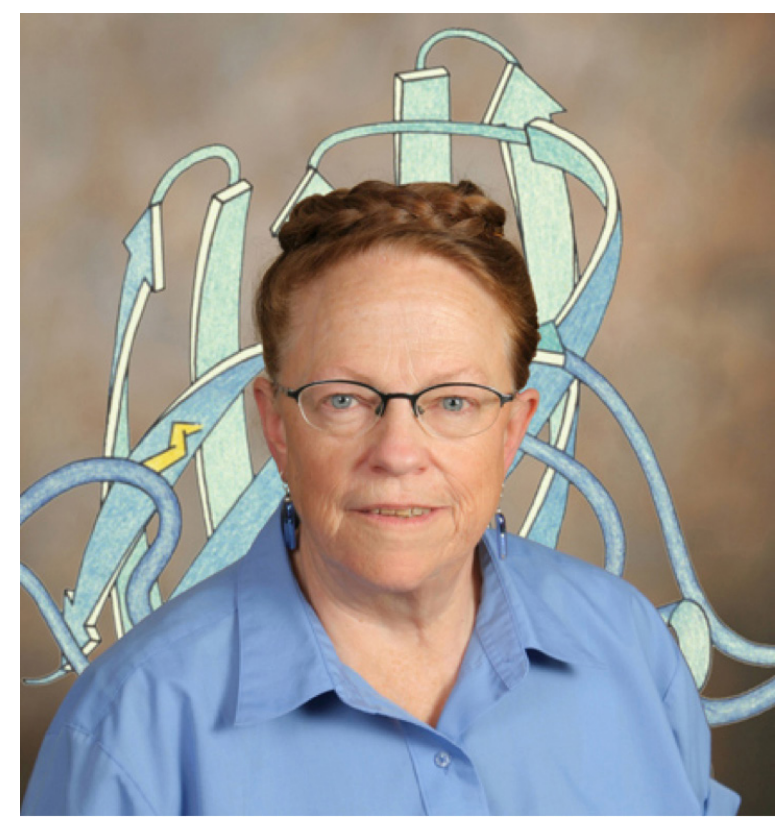

menting the new crystallographic techniques. With this goal, she moved to the University of Amsterdam and later to the University of Pittsburgh (USA) to learn the emerging automatic approaches to solve the crystal structures, an ability that was applied to the development of several programs to the task. In 1966, she returned to the University of Amsterdam, where she accomplished the refinement of the structure of imidazole at low-temperature, structure that she previously had solved at her institution in Madrid using room temperature data, which impeded full refinement. Sagrario was engaged in many national boards with the aim to support and encourage the emergent crystallographic community. She also held international appointments as, for instance, she was committed by the Commission on Crystallographic Apparatus of the IUCr for managing a project on Accuracy in Lattice Parameter Measurement. During her career, Sagrario trained generations of PhD students (the author was one of them) and many chemists willing to make use of crystallography for their research. Her enthusiasm, courage and ability to front any obstacle have been a model for all of us. 
Figure 11. Sagrario Martínez-Carrera (right), with Dorothy Hodgkin and S. C. Abrahams at the International Conference on X-Ray Anomalous Scattering held in Madrid, in 1974.

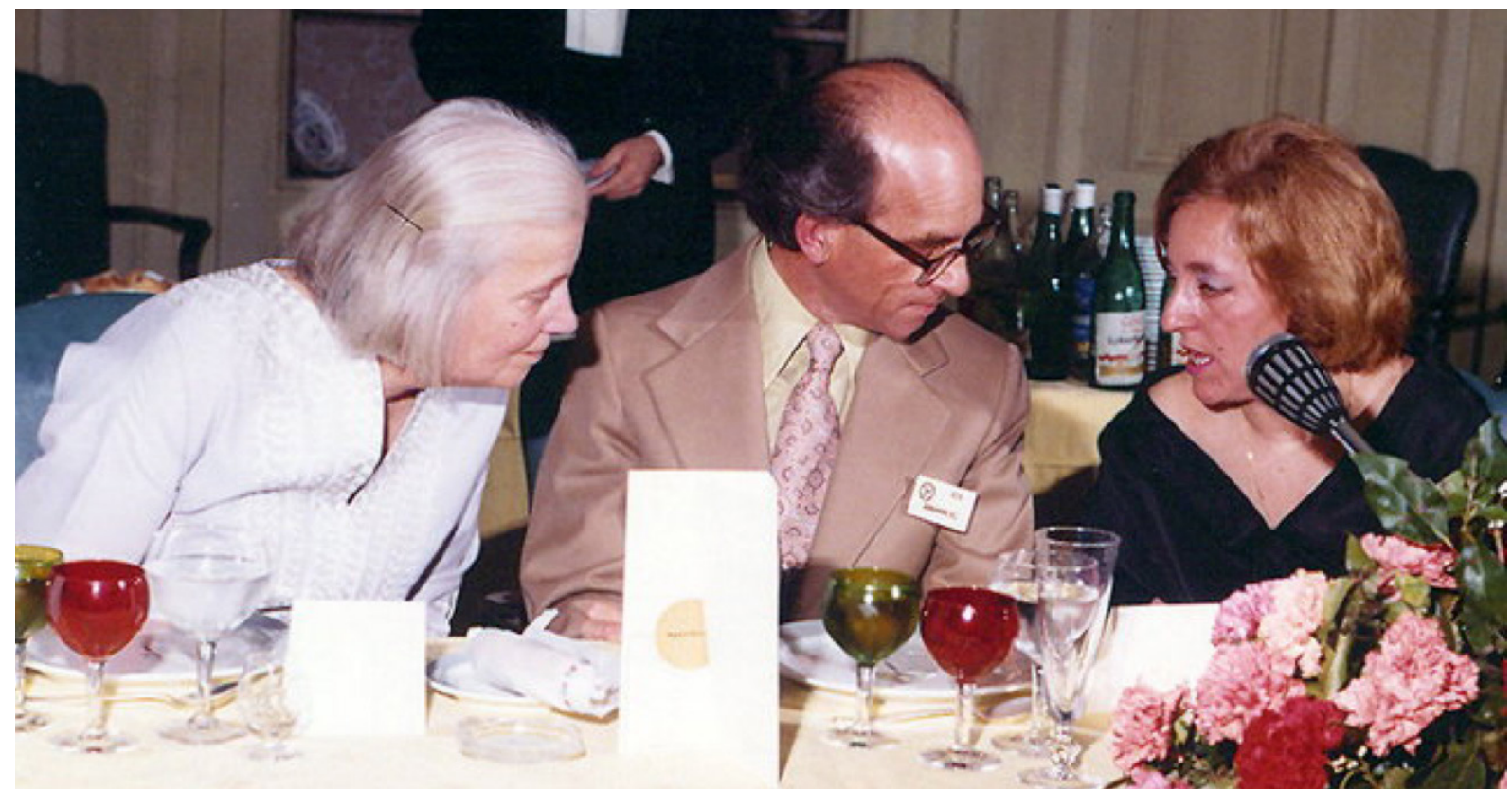

\section{ADA YONATH: THE NEW ERA AND THE RISING OF LIFE SCIENCES}

The extraordinary development of specialized equipment and the increasing automatism of the crystallographic techniques enabled its application to very sophisticated biological systems, which has provided outstanding results in life sciences and has resulted in several Nobel laureates directly related to crystallography in the new century. In 2009, the Israeli crystallographer, Ada E. Yonath (1939-) (Figure 12) received the Nobel Prize in Chemistry, along with the Indian-born American and British Venkatraman Ramakrishnan and the American Thomas A. Steitz, for her studies on the structure and function of the ribosome, becoming the fourth female in the field after forty-five years since Hodkings' Prize.

The ribosome is the cellular organelle catalysing the translation of genetic code into proteins. It is a protein/RNA assembly arranged in two subunits that associate for performing protein biosynthesis. The prokaryotic ribosome contains more than fifty proteins assembled to three RNA chains, what gives an idea of its complexity ( $\approx 2,5$ megaDaltons). In fact, it is the largest structure solved up to now, as some virus solved are bigger but its analysis was simplified us- ing its highly symmetrical scaffold. After twenty years of dedication, Ada studies culminated in 2000 when she determined the structures of the two ribosomal subunits, an achievement ranked by the prestigious Science magazine as among the most important scientific developments of the year. Additionally, Ada elucidated the modes of action of over twenty different antibiotics targeting the ribosome, illuminated mechanisms of drug resistance and synergism, thus paving the way for structure-based drug design. For performing ribosomal crystallography Ada introduced a novel technique, cryo bio-crystallography, which enables X-ray collection at cryogenic temperatures and became routine in structural biology, allowing intricate projects otherwise considered formidable.

Ada Yonath, born in Jerusalem in 1939, had to cope with rather hard origins. Her father was a rabbi and, despite her parents being not wealthy, they wanted to assure her a good education sending her to an upscale school. When her father died being only 10 , the family moved to Tel Aviv, where Yonath was accepted at Tichon Hadash high school although her mother could not pay the cost and she gave math lessons to students in return. She later commented on her hardworking childhood saying that "there was never a spare minute". She moved to Jerusalem to attend the 
Figure 12. Ada Yonath was 2009 Nobel Laureate in Chemistry for her studies on the structure and function of the ribosome (http://bit.ly/1IBeMls), the largest structure solved by X-ray crystallography up to now. She shared de Prize with Venkatraman Ramakrishnan and Thomas A. Steitz.

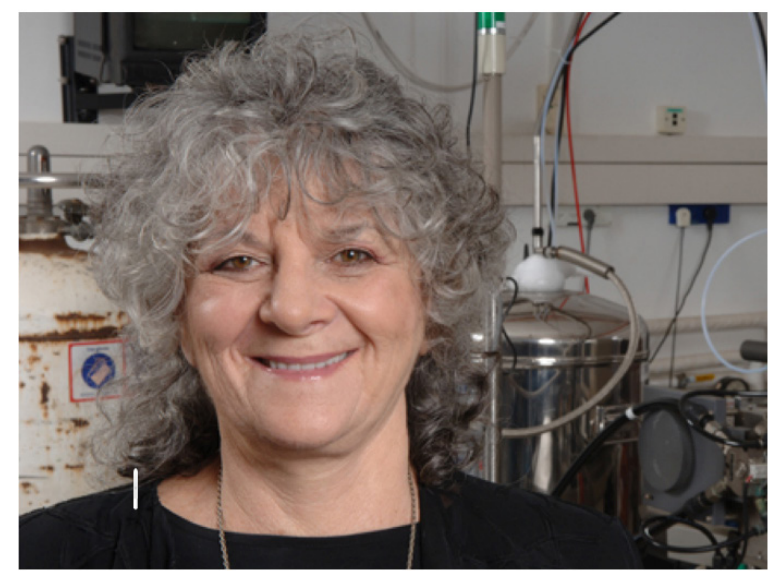

Hebrew University studying chemistry and biochemistry, and went on to earn a doctorate in crystallography from the Weizmann Institute. In 1968 she made postdoctoral studies at the Pittsburgh Carnegie-Mellon University and at the Massachusetts Institute of Technology, and in 1970, Ada joined the Chemistry Department of the Weizmann Institute establishing what for almost a decade was the only protein-crystallography laboratory in Israel. Since then, she has conducted research and held prestigious appointments at universities in Israel, Germany and the United States.

Following her Nobel Prize announcements in 2009, and asked about this in relationship to her gender, she said: "I am a scientist, not male or female. A scientist," "I'm sorry that I can't think this is because of my gender. And, I don't think that I did something that is especially for women, or the opposite. During my time I had some very difficult years and I had very

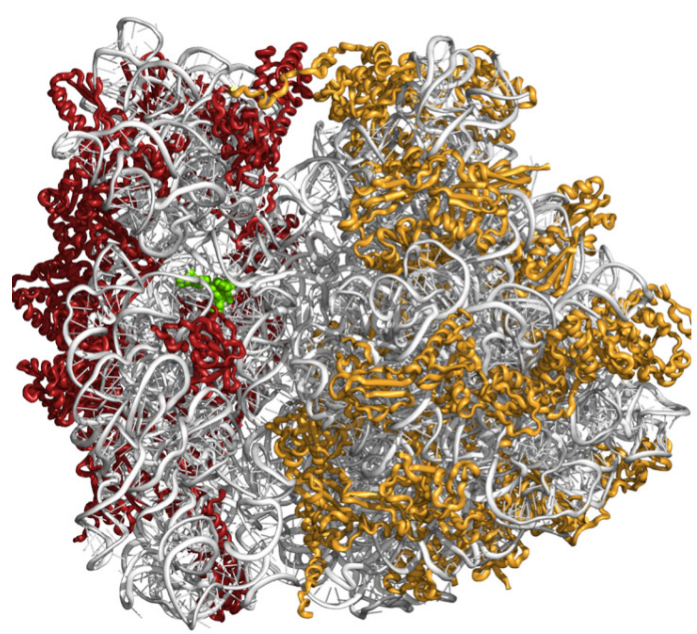

pronounced competition, all by men. But I don't think that this is because I was a woman. I'm pretty sure that if I were a man too they would compete, if the men would get to where I was at that time".

But, yet, she is conscious that this is true only partially, and also she has said: "Women make up half the population." "I think the population is losing half of the human brain power by not encouraging women to go into the sciences. Women can do great things if they are encouraged to do so." "I would like women to have the opportunity to do what is interesting to them, to go after their curiosity. And I would like the world to be open to that. I know in many places there is opposition to that."

Might the aspiration of equal opportunities for all mankind, male or female, became true someday in the future.

\section{REFERENCES}

Glusker, J. P. and Trueblood, K. N. (2010). Crystal Structure Analysis. A Primer ( $3^{\text {rd }}$. ed.). Oxford University Press.

Hodgkin, D. C. (1965). The X-ray Analysis of Complicated Molecules. Science, 150, pp. 979-988. http://dx.doi.org/10.1126/ science.150.3699.979

Karle, I. (1973). Successful Women in the Sciences: Analysis of Determinants. I.
Individual Life Experiences. Crystallographer. Annals of the New York Academy of Sciences, 208, pp. 11-14. http:// dx.doi.org/10.1111/j.1749-6632.1973. tb30812.x

Lonsdale, K. Y. (1931). An X-Ray Analysis of the Structure of Hexachlorobenzene, Using the Fourier Method. Proceedings of the Royal Society, 133, 822, pp. 